\title{
The Transformation of Consonant Sound of English Loanwords into Arabic
}

\author{
Dr. Rika Astari, S.S., M.A. \\ School of Arabic Language and Literature, Faculty of Education and Islamic Studies \\ University of Ahmad Dahlan Indonesia \\ astari.rika@yahoo.co.id
}

\begin{abstract}
This research describes the transformation of sound load words from English into Arabic and explicates the types of its sound transformation. The objects of the research include several Arabic dictionaries such as: Al-Mawrid: A Modern English Arabic Dictionary (2009) by Munir Ba'albaky, Munawwir Digital Program Version 1.1 Al-Wustho Digital Publishing (Munawwir, 2010), the dictionary of Atlas English-Arabic (by Atlas Dictionary, 2005), online newspaper Al-Ahram and Al-Jazeera published from $1^{\text {st }}$ up to $30^{\text {th }}$ June 2011. However, the formal objects are words of science and technology, covering 10 fields of studies; astronomy, biology, pharmacy, physics, geography, medical, chemist, math, farming, and information communication technology. The distributional method and identity method apply in data analysis.

The research concludes that the transformation of consonant sound of loanwords from English into Arabic is typically close to the process of sound articulation. In this case, there are 4 types of sound transformation derived from the typical process of articulation; the sound $[g]$ into $[k],[p]$ into $[b],[s]$ into $[z],[v]$ into $[f]$. Also, there are the distorted transformation of consonant sound to differentiate from another word meaning. The additional sound of Epenthesis type is the most commonly occurred because of the adjustment with the pattern of syllables and sound in Arabic.
\end{abstract}

Keywords: consonant transformation, English loanwords, sound types.

\section{INTRODUCTION}

Language is a mean of communication produced by human articulation organs. In communication, there is a process of sending and receiving messages. The intense interaction between native and nonnative speakers will seemingly promote the process of borrowing.

The borrowing process of foreign language into Arabic has occured far before the revelation of Alqur'an when Arabic has been modified by other languages such as Habsyah, Greek, Latin, Ibrani, Suryani, Indian, Persian, and Turks (At-Tunjī, 2005: 90). In the era of Umayyah, 'Abasiyyah and Turks 'Usmani, Arabic became a national and scientific language. In modern era, the interaction between West and East starts from Libanon that has conjunction with the West since the beginning of seventh century. The mile stone in the history of modern Middle East is the expedition of Napoleon to Eigyp in the year of 1798. This exspedition promoted Egyptology that develop the consequtive relation between Eigyp and Arab world since the nineteenth century (Chejne, 1996: 104). Such relation finally affected the words used in Arabic. The process of borrowing is indispensable during social life, economics, technology, and politics. The influence of English was mostly tangible in the costal area of Arab bay and approximately reached more than three thousand words (Hadi, 2005: 2).

The development of Arabic by borrowing English words as what has been mentioned above, creates several issues due to the different and typical characteristics of each language such as English sounds that are never found in Arabic ones. After English words are borrowed, the articulation follows the sound pattern of Arabic. Based on the previous explanation, this paper formulates two research problems as in the following:

1. How is the transformation of consonant sound of loanwords from English into Arabic?

2. What are the types of the transformation of consonant sound of loanwords from English into Arabic? 


\section{THEORETICAL FRAMEWORK}

\subsection{Theory of Language Interaction}

Language interaction is an exchange process of two languages by the natives. From this process, there is a transfer of language elements into another language from all aspects including word borrowing from one into another language (Hockett, 1958: 402-406). The borrowing and influencing process are irresistible. The influence of a language into another one is diffusion and culture acculturation (Weinreich, 1953:5). If it is analyzed from acculturation indication, the elements of a foreign language will actually be accommodated and integrated into the target language without losing its foreign characteristics. This is the cause of the transformation in the vocabulary of the target language. Crowley (1987: 191-200) argues that the factors of transformation of certain language includes: 1) anatomy and ethnic character; 2) climate and geography); 3) substratum;4) local identification; 5) functional need; 6) simplification; and 7) structural pressure.

In terms of word borrowing, Haugen (1950:286) defines it as: "attempted reproduction in one language of patterns previously found in another" Moreover, he clarifies that the result of borrowing becomes loanwords, loan blends or hybrids, and loan shifts. Loan shifts covers loan translations and semantic borrowings. Meanwhile, loanwords is the result of morphemic import without morphemic substitution but with or phonemic ones. Loan blends is a combination of substitution and morphemic import, but the structure follows the form of original words. Loan blends is also called hybrids; a borrowing combination that has different structure from the original word. Loan blends can be divided into three types namely 1) blended stem;2) blended derivative (suffixes of original words replace the target language); and 3) blended compound (Haugen, 1950: 219).

\subsection{The Principles of Consonant Characters in Arabic Institution (Majma`al-Lugah)}

Arabic countries have Majma'al-Lugah that is basically intended to manage the growing and development of Arabic as part of scientific language and studies. In the $26^{\text {th }}$ congress of 1959 , Majma 'Cairo made 23 principles to internalize characters and sounds of Greek and Latin into Arabic. Meanwhile, in the $30^{\text {th }}$ congress of 1963 , it set principles up of consonant characters. The transformation of those consonant characters can be seen in the following table.

Table1. The list of consonant character transformation

\begin{tabular}{|c|c|c|}
\hline النطق العربي المو افق & الحرف اللاتينى او الإغريقى & 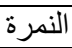 \\
\hline س, ك, نقل (ق) فى التجربة السابقة فقالو ا: أرقاديا:arcadia & $\mathrm{C}$ & 1. \\
\hline$\dot{j}, د$ & $\mathrm{D}$ & 2. \\
\hline ف & $\mathrm{F}$ & 3. \\
\hline ج, & $\mathrm{g}$ & 4. \\
\hline ه, (ونقل (أ) ايضافى التجربة السابقة & $\mathrm{h}$ & 5. \\
\hline تش (بالإنكليزية), شبالألمانية, ك, خ (باليونانية) & $\mathrm{ch}$ & 6. \\
\hline ي (بالألمانية), ج (بالفرنسية), خ (بالإسبانية) & $\mathrm{J}$ & 7. \\
\hline$\ddot{\varphi}$ & $\mathrm{p}$ & 8. \\
\hline ف & ph- $\phi$ & 9. \\
\hline 5] & $\mathrm{k}$ & 10. \\
\hline ك, نقل (ق) فى التجربة السابقة فقالو ا: قونطوسفى: qwintus & $\mathrm{q}$ & 11. \\
\hline تق, نقل (ط) فى التجربة السابقة, فقالو ا : طيطوسفى: titus & $\mathrm{T}$ & 12. \\
\hline 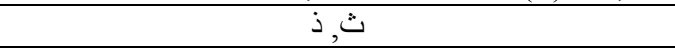 & th- $\theta$ & 13. \\
\hline س,ش, ص & $\mathrm{S}$ & 14. \\
\hline ث & $\mathrm{V}$ & 15. \\
\hline ث, & $\mathrm{W}$ & 16. \\
\hline كس, ك, س, كز, خ & $\mathrm{X}$ & 17. \\
\hline j j & $\mathrm{Z}$ & 18. \\
\hline ب بـ & $\psi$ & 19. \\
\hline
\end{tabular}

\subsection{The Theory of Sound Transformation}

According to Sloat, sound transformation is a natural process. Natural process itself covers two major parts including assimilatory process and non-assimilatory process. In the case of sound transformation types, Sloat divides into:

1) assimilatory process: the most common transformation of sound is related to the assimilation of a sound with another one. Assimilation is a natural process that often happens. The following are the 
types of assimilation: a) nasalization; b) nasal assimilation; c) palatalization; d) assibilation; e) intervocalic voicing; f) intervocalic weakening; g) vowel assimilation; h) umlaut.

2) non-assimilatory process: it belongs to the process excluding assimilation one. The types of the transformation of non-assimilatory include: a) rhotacism; b) breaking; c) vowel reduction ; d) apocope; e) syncope; f) prothesis; g) epenthesis; h) metathesis; i) dissimilation. On the other hand, Crowley (1992: 38-58) classifies the types of sound transformation into: 1) lenition and fortition including aphresis, apocope, syncope, cluster reduction, haplology; 2) sound addition: excrescence, epenthesis, prothesis; 3) metathesis; 4) fusion; 5) unpacking; 6) vowel breaking); 7) asimilation; 8) dissimilation; 9) abnormal sound change.

\section{RESEARCH METHOD}

\subsection{Primary Data}

This research limits the scope focusing on the English loanwords in the field of science and technology. The writer opts those fields of study because they belong to the most developed field from many different angles. The material object of this research is the Arabic dictionary such as: $A l$ Mawrid: A Modern English Arabic Dictionary (2009) by Munir Ba'albaky, Munawwir Digital Program Version 1.1 Al-Wustho Digital Publishing (Munawwir, 2010), Atlas English-Arabic dictionary (team of Atlas dictionary, 2005), online newspaper Al-Ahram and Al-Jazeera that are published from 1 to 30 June 2011. However, the formal objects are words of science and technology, covering 10 fields of study; astronomy, biology, pharmacy, physics, geography, medical, chemist, math, farming, and information communication technology. The reasons behind those ten fields of study are 1) those fields become the foundation of science such as math, biology, physic, and chemist; 2) Those fields generally have a conjunction with human life such as astronomy, pharmacy, medical, farming, and geography; 3) The third reason relates to the globalization era in which information from all over the world can be immediately accessed by using information communication technology. In this case, language functions as a communication tool that its development is influenced by the development of science and technology.

\subsection{Data Collection}

The first step in this research is data collection of loanwords in the field of science and technology. In relation to that, the data collection number of either loan or non-loanwords are 1824 items derived from the field of astronomy (320), geography (101), farming (46), biology (282), physic (224), chemist (149), medical (258), math (210), pharmacy (101), and technology information system (133). The data is populated by reviewing and taking a note on the assumption that the words originated from English. Respectively, the researcher checks up their articulation in the dictionary of Merriam Webster Atlas English-Arabic (2005). To get the phonemic transcription data from English words, the writer occupies interview technique from English and Arabic native speakers. At the end, the final data are input and tabulated in a computer.

\subsection{Data Analysis}

At this stage, the writer applies distributional method to analyze the data. The distributional method is an analysis method that uses language elements or the correlation between its language phenomena as the determiner. The description of this method is visible in the analysis technique of deconstruction upon its smallest lingual particles. This method is occupied to analyze the sound transformation of English words into Arabic one based on phonemic transcription certified by IPA (The International Phonetic Alphabet). The method deconstructs the sound transformation from English into Arabic. To reveal all issues involving English and Arabic, the writer occupies the method of translational similarity. This method is used to compare research elements which is analyzed in Arabic by using the matching tools of English elements.

\section{ANALYSis OF SOUND Transformation}

Based on the data collection, the writer will explain about the analysis of sound transformation of English words into Arabic based on IPA (International Phonetic Alphabet), the sound pattern, and phono tactic of Arabic. After that, there will be a summary of sound transformation types in the data collection based on the theories in the previous chapter. Basically, Arabic has 28 consonants and 6 vocals (Abbound, 1996:2). Among the 28 consonants, there are 15 consonant that has similar sounds 
in English namely $\left.[\mathrm{d}],[\mathrm{w}],[\mathrm{b}],[\mathrm{n}],[\mathrm{f}],[\mathrm{t}],[\mathrm{f}],[\mathrm{j}],[\mathrm{m}],[\theta],[\mathrm{s}],[\mathrm{z}],\left[\int\right],[\mathrm{k}],[\mathrm{d}\}\right]$. Based on the data, the sounds $[\mathrm{b}],[\mathrm{d}],[\mathrm{f}],[\mathrm{h}],[\mathrm{k}],[\mathrm{l}],[\mathrm{m}],[\mathrm{n}],[\mathrm{r}],[\mathrm{t}],[\mathrm{w}],[\mathrm{z}],[\mathrm{j}],[\mathrm{g}]$ from English words do not change their sounds in Arabic in the position of pre, mid, and post distribution word as shown in the following table:

Table2. Phoneme that do not have sound transformation in English loanwords

\begin{tabular}{|c|c|c|c|c|c|c|c|}
\hline No & Phoneme & Distribution & English & $\begin{array}{c}\text { Phonemic } \\
\text { transcription }\end{array}$ & Arabic & $\begin{array}{l}\text { Ortho graphic } \\
\text { transcription }\end{array}$ & $\begin{array}{c}\text { Phonemic } \\
\text { transcription }\end{array}$ \\
\hline 1 & \multirow{2}{*}{$b$} & pre & barite & [berajt] & باريت & bārīt & [ba:ri:t] \\
\hline 2 & & mid & cable & [kebəl] & كَبْل & kabl & {$[\mathrm{kabl}]$} \\
\hline 3 & \multirow{2}{*}{ d } & pre & decameter & [dikamitər] & ديكامتز & dīkāmitr & [di:ka:mitr] \\
\hline 4 & & mid & hydraulic & [hajdrolık] & هيدروليكيّ & hidrūlīkiyy & [hidru:li:kI] \\
\hline 5 & \multirow{2}{*}{$\mathrm{f}$} & pre & flora & [florə] & فُلورَة & falwarah & [falawroh] \\
\hline 6 & & mid & paraffin & [perəfən] & بار افين & bārāfīn & [ba:ra:fi:n] \\
\hline 7 & \multirow{2}{*}{$\mathrm{k}$} & Pre & kinetoscope & [kənctoskop] & كَيْنَتو سكوب & kainatuskūb & [kəinatusku:b] \\
\hline 8 & & Mid & leukemia & [lukimiə] & لُوكيميا & lūkīmiyā & [lu:ki:mija:] \\
\hline 9 & \multirow{3}{*}{1} & Pre & langley & [læyli] & لأنغلي & lan-galiy & [layghali:] \\
\hline 10 & & Mid & astrolabe & [æz tro leb] & أسنطرَّْلاب & usṭ urlāb & [?ust'surla:b] \\
\hline 11 & & Post & cholesterol & [kəlestərol] & كلولسترول & kalūlistirūl & [kalu:listiru:1] \\
\hline 12 & \multirow{3}{*}{$\mathrm{m}$} & Pre & methionine & 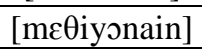 & ميثيونين & mīs̀yī ūnīn & [mi:Jiju:ni:n] \\
\hline 13 & & Mid & automatic & [ptəmætık] & أوتوماتي & ūtūmātīy & [al?u:tu:ma:ti:] \\
\hline 14 & & post & iridium & [IrIdiəm] & إريديوم & īrīdiyūm & [alPiri:diju:m] \\
\hline 15 & \multirow{3}{*}{$\mathrm{n}$} & Pre & nucleonics & [nəklianıks] & نُوَوَِيّات & nuwawiyyāt & [annuwajja:t] \\
\hline 16 & & Mid & oceanographer & $\begin{array}{l}\text { [ofənagrəfər } \\
\text { om mitər] }\end{array}$ & | أو قيانو غر افيّ & ūqiyānugrāfiy & [u:qija:nuyra:fI] \\
\hline 17 & & Post & electron & [əlektran] & ألكترون & alukturūn & [aluktru:n] \\
\hline 18 & \multirow{3}{*}{$\mathrm{r}$} & Pre & robotization & [robatisəðən] & رَبوطة & rabūṭah & [robu: $\left.t^{\dagger} a h\right]$ \\
\hline 19 & & Mid & barometer & bəramətər] & بارومتر & bārūmitr & [ba:ru:mitr] \\
\hline 20 & & Post & scooter & [skutər] & سكُتْورة & saktūrah & [saktu:roh] \\
\hline 21 & \multirow{3}{*}{$\mathrm{t}$} & pre & tyrosine & [tairosin] & تيروسين & tīrūsīn & [ti:ru:si:n] \\
\hline 22 & & Mid & tantalum & [tæntələm] & تُتنتالوم & tantālūm & [tanta:lu:m] \\
\hline 23 & & Post & basalt & [bəsplt] & بازلتية & bāzaltīyyah & [ba:zalti:] \\
\hline & $\mathrm{W}$ & Pre & warfarin & [warfərin] & وَرْفرين & warfarīn & [warfari:n] \\
\hline 24 & \multirow{3}{*}{$Z$} & Pre & zymology & [zaimolədzI] & زيمولوجيا & zìmūlūjiyā & $\begin{array}{l}\text { [zi:mu:lu: } \\
\text { dzija:] }\end{array}$ \\
\hline 25 & & Mid & hydrazine & [hajdrəzin] & هيدرازين & hidrūzīn & [hidru:zi:n] \\
\hline 26 & & Post & influenza & [Influenzə] & انفلونة ا & infaluwanzā & [infaluwanza:] \\
\hline 27 & $\mathrm{j}$ & Pre & uranium & [jəreniəm] & يور انيوم & yurāniyūm & [alju:ro:niju:m] \\
\hline 28 & $y$ & mid & zincic & [zinkik] & زنكي & zinkī & [zinkI] \\
\hline
\end{tabular}

The details of the explanation of sound transformation of English loanwords into Arabic are in the following:

\subsection{The Sound Transformation of Plosive Consonant [g] into [y], [k]}

The sound $[\mathrm{g}]$ does not exist in Arabic. It $[\mathrm{g}]$ can be articulated with the phoneme $[\mathrm{\gamma}]$ or $[\mathrm{k}]$ when Arabic borrows English words. The sound [g] with such distribution represents the sound $[\mathrm{g}]$ like the

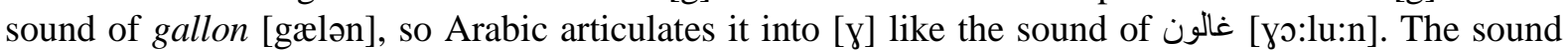
$[\mathrm{g}]$ is a velar consonant sound, plosive, but the sound $[\mathrm{\gamma}]$ is velar consonant, fricative. The sound $[\mathrm{g}]$ and $[\mathrm{y}]$ are two similar sounds that have one difference. The sound $[\mathrm{g}]$ and $[\mathrm{\gamma}]$ are similar consonant sounds that has articulation spot in the velar area. The sound $[\mathrm{g}]$ is articulated by blowing, meanwhile the sound $[\mathrm{\gamma}]$ belongs to displaced sounds. The sound $[\mathrm{k}]$ belongs to velar blow consonant and articulated by blowing method. Thus, the transformation $[\mathrm{g}]$ into $[\gamma]$ tends to be similar compared to the sound [k]. Nonetheless, in the word case of galvanism [galvanisəm] into كَلفنانية [kalfa:nijjah], the sound $[\mathrm{g}]$ is articulated with the sound [k]. This case happens due to potency of misunderstanding. If

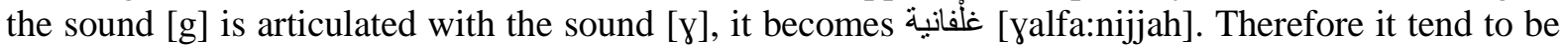
the sound الغلفة meaning 'kulup' in Arabic. The samples of sound transformation [g] into [y], [k] can be seen in the following table:

Table3. Sound transformation $[g]$ into $[\mathrm{\gamma}],[\mathrm{k}]$ 
The Transformation of Consonant Sound of English Loanwords into Arabic

\begin{tabular}{|c|c|c|c|c|c|c|c|}
\hline No & Distribution & English & $\begin{array}{l}\text { Phonemic } \\
\text { transcription }\end{array}$ & Arabic & $\begin{array}{l}\text { Orto graphic } \\
\text { transcription }\end{array}$ & $\begin{array}{c}\text { Phonemic } \\
\text { transcription }\end{array}$ & $\begin{array}{c}\text { Sound } \\
\text { transformation }\end{array}$ \\
\hline 1. & \multirow{7}{*}{ pre } & gallon & [gælən] & غالون & gālūn & [ชo:lu:n] & $\mathrm{g} \rightarrow \mathrm{\gamma}$ \\
\hline 2. & & gas oline & [gæs olin] & غازولين & gāzūlīn & 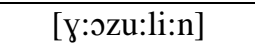 & $g \rightarrow \gamma$ \\
\hline 3. & & glauconite & [glasonait] & غلوكونيت & gulūkūnīt & [yulu:ku:ni:t] & $g \rightarrow \gamma$ \\
\hline 4. & & $\begin{array}{l}\text { gram or } \\
\text { gramme }\end{array}$ & [græm] & غُرْام & garām & [yra:m] & $g \rightarrow \gamma$ \\
\hline 5. & & granite & [grænət] & غر انيت & garīnīt & [yaro:ni:t] & $g \rightarrow \gamma$ \\
\hline 6. & & graphology & [grəfalədzi] & غُر افولوجيا & garāfūlūjiyā & [yro:fu:lu: dzija:] & $g \rightarrow \gamma$ \\
\hline 7. & & galvanism & [galvanisəm] & كَّلَفانية & kalfāniyyah & [kalfa:nijja] & $\mathrm{g} \rightarrow \mathrm{k}$ \\
\hline 8. & mid & giga hertz & [dzigahertəz] & جِيغاهيرتز & jīgāhirtiz & [dzi:ya:hirtəz] & $g \rightarrow \gamma$ \\
\hline
\end{tabular}

\subsection{The Sound Transformation of Plosive Consonant $[p]$ into [b]}

The sound [p], distributed at pre, mid, and post words, is articulated with the sound [b] when Arabic borrows it. It happens because the sound does not exist in Arabic as in the word case of pantology [pəntэlojI] into بَنْولوجيا [banto:lu:dziya:]. The sound [p] is actually the consonant sound of bilabial, plosive. Meanwhile, the sound [b] belongs to the consonant sound of bilabial, plosive. The sound [p] and $[\mathrm{b}]$ are equally the consonant sounds that are articulated by blowing and have articulation spot at bilabial area. The difference of them are solely in the case of vocal cord vibration. The sound $[\mathrm{b}]$ belongs to the sound of voice, meanwhile the sound $[\mathrm{p}]$ is the voiceless one. The following table describes the loanwords from English that represents the sound $[\mathrm{p}]$ at the pre, mid, and post words.

Table4. The sound transformation $[p]$ into $[b]$

\begin{tabular}{|c|c|c|c|c|c|c|c|}
\hline No & Distribution & English & $\begin{array}{c}\text { Phonemic } \\
\text { transcription }\end{array}$ & Arabic & $\begin{array}{l}\text { Orto graphics } \\
\text { transcription }\end{array}$ & $\begin{array}{c}\text { Phonemic } \\
\text { transcription }\end{array}$ & $\begin{array}{c}\text { Sound } \\
\text { transformation }\end{array}$ \\
\hline 1. & \multirow{4}{*}{ pre } & panchromatic & [peykəmətik] & بانكروماتيّ & bānkurūm ātiy & [baykro:matI] & $\mathrm{p} \rightarrow \mathrm{b}$ \\
\hline 2. & & pantology & [pəntoləjI] & بَنْتولوجيا & bantūlūjiyā & [banto:lu: dziya:] & $\mathrm{p} \rightarrow \mathrm{b}$ \\
\hline 3. & & paraffin & $\begin{array}{l}\text { [perəfən } \\
\text { perəfə'n] }\end{array}$ & بار افين & bārāfīn & [ba:ra:fi:n] & $\mathrm{p} \rightarrow \mathrm{b}$ \\
\hline 4. & & proton & [protan] & بروتون & burūtūn & [bars:tu:n] & $\mathrm{p} \rightarrow \mathrm{b}$ \\
\hline 5. & mid & - & - & - & - & - & - \\
\hline 6. & \multirow{2}{*}{ post } & & & & & & \\
\hline 7. & & gyroscope & [dzajrəskop] & جيروسكوب & jīrūskūb & [dzi:rusku:b] & $\mathrm{p} \rightarrow \mathrm{b}$ \\
\hline
\end{tabular}

\subsection{The Sound Transformation of Fricative Consonant [s] into [J], [z]}

The sound [s] at the pre of English words is articulated with the sound [ $[$ ] and [s] when Arabic borrows them. The sound [s], positioned at the pre of words, becomes the sound [J]. The sound [s] is alveolar consonant, fricative. Meanwhile the sound $[S]$ belongs to the post alveolar consonant, fricative. All of them is part of voiceless sounds. The sound transformation [s] into [ $]$ ] is seemingly affected by the post vocal sound [o] that comes after the sound [s], like in the case of sodic [sodik] into صوديوميّ [〕:diju:m]. Therefore, the sound [s] in such case, follows the sound [o] and altered into the sound [J].

The sound [s] in the mid of English words is articulated [s], like in the words of stroboscope [strobosksp]. Thus, that sound is still mentioned as the sound [s]. If it is positioned at the post of words like in words of soubise [sobais], the sound [s] changes into the sound [z]. The sound transformation [s] into [z] tend to be influenced by the end vocal sound [o] that is distributed after the sound [s]. The sound [s] is alveolar consonant, fricative, meanwhile the sound [z] belongs to alveolar consonant, fricative. The difference between them is in the case of vocal cord vibration. The sound [s] is part of voiceless group, meanwhile the sound [z] is part of the voice one. The following table describes the loanwords from English that represent the sound [s] at the pre, mid, and post of words.

Table5. The sound transformation [s] into [J], [z].

\begin{tabular}{|l|c|c|c|c|c|c|c|}
\hline No & Distribution & English & $\begin{array}{c}\text { Phonemic } \\
\text { transcription }\end{array}$ & Arabic & $\begin{array}{c}\text { Orto graphic } \\
\text { words }\end{array}$ & $\begin{array}{c}\text { Phonemic } \\
\text { transcription }\end{array}$ & $\begin{array}{c}\text { Sound } \\
\text { transformation }\end{array}$ \\
\hline 1. & Pre & saccharin & [sækərən] & sakn & sukkarin & [sukkari:n] & $\mathrm{s} \rightarrow \mathrm{s}$ \\
\hline
\end{tabular}


Dr. Rika Astari, S.S.

\begin{tabular}{|c|c|c|c|c|c|c|c|}
\hline 2. & & saccharine & [sækərajn] & سُكَريّ & sukkariy & [sukkarI] & $\mathrm{s} \rightarrow \mathrm{s}$ \\
\hline 3. & & saccharose & [sækəros] & السُّكُروز & sukkarūz & [sukkaro:z] & $\mathrm{s} \rightarrow \mathrm{s}$ \\
\hline 4. & & scooter & [skutər] & السَّكْتُورة & saktūrah & [saktu:roh] & $\mathrm{s} \rightarrow \mathrm{s}$ \\
\hline 5. & & seismogram & [sajzmagram] & السيّيزموغرام & sīzmūgrām & [sizmu:gra:m] & $\mathrm{s} \rightarrow \mathrm{s}$ \\
\hline 6. & \multirow{9}{*}{ Mid } & sodic & [sodik] & صوديوميّ & șūdiyūm & [〕ว:diju:m] & $\mathrm{s} \rightarrow \int$ \\
\hline 7. & & sodium & [sodiəm] & الصُوّوديوم & șūdiyūm & [§o:diju:m] & $\mathrm{s} \rightarrow \int$ \\
\hline 8. & & stroboscope & [strobəskっp] & السّتروبوسكوب & sitrūbūskūb & [sitru:bosks:b] & $\mathrm{s} \rightarrow \mathrm{s}$ \\
\hline 9. & & statoscope & [statosksp] & الستاتو سكوب & satātskūb & [sata:tusks:b] & $\mathrm{s} \rightarrow \mathrm{s}$ \\
\hline 10. & & congress & [kaygros] & الكونجرس & kunjiras & [kundzras] & $\mathrm{s} \rightarrow \mathrm{s}$ \\
\hline 11. & & autobus & [pto bəs] & الأوتوبوس & ūtūbūs & [u:tu:bus] & $\mathrm{s} \rightarrow \mathrm{s}$ \\
\hline 12. & & nitrocellulose & [najtroseljəlos] & النُّروستَلولوز & nitrūsalūlūz & [nitru:salu:lu:z] & $\mathrm{s} \rightarrow \mathrm{z}$ \\
\hline 13. & & diabetes & [dajabitiz] & الذَّبابيتس & diyābits & [dija:bi:ts] & $\mathrm{s} \rightarrow \mathrm{s}$ \\
\hline 14. & & digitalis & [didzətæləs] & الديجيتاليس & dītālīs & [di:dzi:ta:li:s] & $\mathrm{s} \rightarrow \mathrm{s}$ \\
\hline
\end{tabular}

\subsection{The Sound Transformation of Fricative Consonant [f] into [q], [k]}

The sound transformation $\left[\int\right]$ into other sounds is described in the following table:

Table6. The sound symbol [J]

\begin{tabular}{|c|c|c|c|}
\hline \multirow{2}{*}{ Basic sound } & \multicolumn{3}{|c|}{ Transformation } \\
\hline & Sound & Symbol & Description \\
\hline \multirow{2}{*}[\int]{} & $\mathrm{q}$ & ق & [q] the consonant sound of uvular plosive \\
\hline & $\mathrm{k}$ & 5] & [k] the blowing voiceless velar consonant \\
\hline
\end{tabular}

The sound $\left[\int\right]$ is part of post-alveolar consonant, fricative. This kind of sound exists in English and Arabic. In the word case of oceanography [ofənagrəfər] which is borrowed in [u:qija:nuyro:fI], the sound [J] is articulated with [q]. The sound [J] is a post alveolar consonant, fricative, meanwhile the sound [q] is uvular, plosive. The difference between them is in the case of vocal cord vibration. The sound [ $]$ ] belongs to voiceless sound, meanwhile the sound [q] is part of the voice sound. The sound transformation [J] into [q] tends to be influenced by the post vocal sound [o] that is distributed before [ $\left.\int\right]$. Therefore, the sound articulation [o] follows the sound [q] that is also post consonant.

The sound $\left[\int\right]$ is articulated with $[\mathrm{k}]$ if it is distributed in the middle like in case of machinist [mIfinəst] into ميكانيكي [mi:ka:nikI]. The sound [J] is part of post alveolar consonant, fricative. On the other hand, [k] belongs to velar consonant. All of them is voiceless sounds. The sound transformation $\left[\int\right]$ into [k] in the mid of words is seemingly influenced by the sound of pre vocal that is distributed before and after it. Also, it adjusts with the sound [k] that is distributed at the last syllables. If it is positioned at the end of words, it is shed and replaced with [h]. It happens because the sound [J] is distributed in suffix-tion, like in the case of carbonation [karbənəJən] into كَرْبَنَ [karbanah]. The words samples in case of transformation sound [S] into [q] are presented in the following table:

Table7. The sound transformation of [J] into [q]

\begin{tabular}{|c|c|c|c|c|c|c|c|}
\hline No & Distribution & English & $\begin{array}{c}\text { Phonemic } \\
\text { transcription }\end{array}$ & Arabic & $\begin{array}{l}\text { Orto graphic } \\
\text { transcription }\end{array}$ & $\begin{array}{c}\text { Phonemic } \\
\text { transcription }\end{array}$ & $\begin{array}{c}\text { Sound } \\
\text { transformation }\end{array}$ \\
\hline 1 & Pre & - & & & & & \\
\hline 2 & \multirow{3}{*}{ mid } & oceanographer & [ofənagrəfər] & أوقيانو غر افيّ & ūqiyānūgarāfìy & $\begin{array}{c}\text { [u:qija:nughro } \\
\text { :fI] }\end{array}$ & $\int \rightarrow \mathrm{q}$ \\
\hline 3 & & oceanography & [ofənagrəfi] & أوقيانو غر افيا & ūqiya:nugārāfiyya: & [u:qiya:nuy ro:fijja:] & $\int \rightarrow q$ \\
\hline 4 & & machinist & [mI [inəst] & ميكانيكيّ & mīkānīkīy & [mi:ka:nikI] & $\int \rightarrow \mathrm{k}$ \\
\hline 5 & \multirow{7}{*}{ Post } & automation & 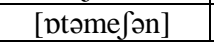 & أوتوماتيكية & ūtūmātīkiyyah & [u:tu:ma:tikijja] & $\int \rightarrow h$ \\
\hline 6 & & carbonation & [karbən $\left.\partial \int \partial n\right]$ & كَرْبَنَة & karbanah & [karbanah] & $\int \rightarrow h$ \\
\hline 7 & & chlorination & 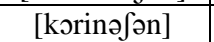 & كَلَوَرة & kalwarah & [kalwaroh] & $\int \rightarrow h$ \\
\hline 8 & & automation & 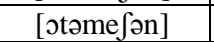 & أتمتة & atmitah & [atmitah] & $\int \rightarrow h$ \\
\hline 9 & & carbonation & 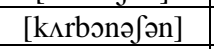 & كَرْبَنَة & karbanah & [karbanah] & $\int \rightarrow h$ \\
\hline 10 & & robotization & [robotisəfən] & رَّبوطة & rabūṭ ah & [robu: $t^{\dagger} \mathrm{sh}$ & $\int \rightarrow h$ \\
\hline 11 & & vulcanization & 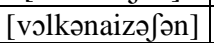 & فَلَكنة & falkanah & [falkanah] & $\int \rightarrow h$ \\
\hline
\end{tabular}

The words in the above table has been synchronized with the principles of phono tactic. It means that all characters come from different articulation spots. It does not populate 4 characters with vowels. Also, there is a harmony among the vowels.

\subsection{The Sound Transformation of Fricative Consonant [ $\theta]$ into [tijj]}

The sound $[\theta]$ exists in English and Arabic. If it is distributed in the pre and mid of words, the sound $[\theta]$ keeps articulated with $[\theta]$ in Arabic. If it is positioned at the post of words, the sound $[\theta]$ is shed 
and replaced with تيّ [tijj]. It happens because such words means a character or behaviour like in the

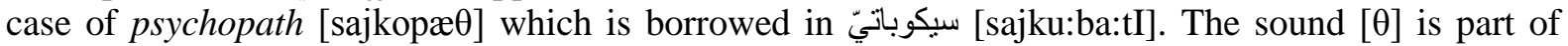
frikatif phoneme, dental. The following table exhibits the samples of sound transformation [ $\theta]$ :

Table8. The sound transformation [ $\theta]$ into [tijj]

\begin{tabular}{|c|c|c|c|c|c|c|c|}
\hline No & Distribution & English & $\begin{array}{l}\text { Phonemic } \\
\text { transcription }\end{array}$ & Arabic & $\begin{array}{l}\text { Orto graphic } \\
\text { transcription }\end{array}$ & $\begin{array}{l}\text { Phonemic } \\
\text { transcription }\end{array}$ & $\begin{array}{c}\text { Sound } \\
\text { transformation }\end{array}$ \\
\hline 1 & \multirow{4}{*}{ pre } & thallic & 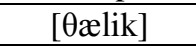 & ثناليوميّ & ṡāliyūm & [Өa:liju:m] & $\theta \rightarrow \theta$ \\
\hline 2 & & thallium & 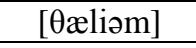 & أثُليوم & ṡāliyūm & [Өa:liju:m] & $\theta \rightarrow \theta$ \\
\hline 3 & & thiosulfate & [ [ayəsulfət] & ثايو كبريتات & śāyūkibrītāt & [Өa:yu:kibri:ta:t] & $\theta \rightarrow \theta$ \\
\hline 4 & & thermometer/ & $\theta ə r m a m ə t ə r$ & شرمومتر & sirmūmitr & [0irmu:mitr] & $\theta \rightarrow \theta$ \\
\hline 5 & post & psychopath & [sajkopæ $\theta$ ] & سيّكوباتيّ & sajkūbātī & [sajku:ba:ti:] & $\theta \rightarrow \mathrm{tijj}$ \\
\hline
\end{tabular}

The words in the table has been synchronized with the principles of phono tactic. It means that all characters come from different articulation spots. It does not populate 4 characters with vowels. Also, there is a harmony among the vowels.

\subsection{The Sound Transformation of Fricative Consonant [v] into [f], [q]}

The sound [v] does not exist in Arabic. After the borrowing process from English into Arabic, the sound [v] becomes [f] or [q]. The sound [v] in the pre of words is articulated with [f], like in the case of vanadinite [vənedinait] into فانادِينيت [fa:na:di:ni:t]. The sound [v] in the mid of English words is articulated [v]. However, in the case of avidin [ævidən], it changes into [q] in the words of [a:qi:di:n]. Based on the above case, the sound [v] is articulated with [q] in order to differentiate with the similar word in Arabic; أفد. The sound [v] is part of fricative labiodental consonant. The sound [f] is the sound of fricative labiodental consonant. On the other hand, the sound [q] belongs to plosive uvular consonant. The sound [v] and [f] are similarly in the group of displaced sound and have the articulation spot in labiodental area. The difference between them is merely in the case of vocal cord vibration. The sound [f] is displaced voiceless, meanwhile [v] belongs to voice. On the other hand, the sound [q] is part of uvular consonant. Thus, the transformation [v] into [f] basically tend to have similar sound toward the original sound compared to the sound [q]. In the case of avidin [ævidən] into آفيدين [a:qi:di:n], the sound [v] is articulated with [q]. If it is articulated with [f], the words will be [a:fi:di:n] that will be similar with other words in Arabic. The following table will explain about the English loanwords that represent the sound [v] in the pre, mid, and post of words.

Table9. The sound transformation [v] into [f]

\begin{tabular}{|c|c|c|c|c|c|c|c|}
\hline No & Distribution & English & $\begin{array}{c}\text { Phonemic } \\
\text { transcription }\end{array}$ & Arabic & $\begin{array}{l}\text { Orto graphic } \\
\text { transcription }\end{array}$ & $\begin{array}{c}\text { Phonemic } \\
\text { transcription }\end{array}$ & $\begin{array}{c}\text { Sound } \\
\text { transformation }\end{array}$ \\
\hline 1. & \multirow{8}{*}{ pre } & vanadic & [vənedik] & فاناديوميّ & fānādiyūmī & [fa:na:dijumI] & $\mathrm{v} \rightarrow \mathrm{f}$ \\
\hline 2. & & vanadinite & [vənedinait] & فانادِينيت & fānādīnīt & [fa:na:di:ni:t] & $\mathrm{v} \rightarrow \mathrm{f}$ \\
\hline 3. & & vanadium & [vənediəm] & فاناديوم & fānādiyūm & [fa:na:diju:m] & $v \rightarrow f$ \\
\hline 4. & & vietminth & [viktmin] & فِفَتْمِنْهُ & fiyatminah & [fijatmina] & $\mathrm{v} \rightarrow \mathrm{f}$ \\
\hline 5. & & vitelin & [vajtəlin] & فيتالين & fìtālīn & [fi:ta:li:n] & $\mathrm{v} \rightarrow \mathrm{f}$ \\
\hline 6. & & volt & [volt vol $\left.{ }^{t}\right]$ & فُلْط: الفولت & fult & {$\left[\mathrm{fol} \mathrm{t} \mathrm{t}^{\mathrm{s}}\right]$} & $\mathrm{v} \rightarrow \mathrm{f}$ \\
\hline 7. & & voltage & [voltədz] & فُلْطيَة & fult iyyah & [ful țijjah] & $\mathrm{v} \rightarrow \mathrm{f}$ \\
\hline 8. & & vulcanite & [volkənait] & فلكانيت & falkānīt & [falka:ni:t] & $\mathrm{v} \rightarrow \mathrm{f}$ \\
\hline 9. & \multirow{2}{*}{ mid } & galvanism & [galvanisəm] & كألففانية & kalfāniyyah & [kalfa:ni:] & $\mathrm{v} \rightarrow \mathrm{f}$ \\
\hline 10. & & avidin & [ævidən] & آقيدين & āqīdīn & [a:qi:di:n] & $\mathrm{v} \rightarrow \mathrm{q}$ \\
\hline & post & - & - & - & - & - & - \\
\hline
\end{tabular}

\section{The AnAlysis OF TyPes OF SOUND Transformation}

Based on the theories in the chapter of theoretical framework, the sound transformation from English words into Arabic shows the similar indication on the types of sound transformation theories. The analysis of types of sound transformation is as in the following:

\subsection{Intervocalic Weakening}

Intervocalic weakening is sound transformation due to the assimilation of resistant sounds into continue ones (Sloat, 1978:112). In the case of loanwords from English into Arabic, there is transformation of blowing consonant sound $[\mathrm{g}]$ into fricative consonant $[\mathrm{\gamma}]$ that is described in the following image: 


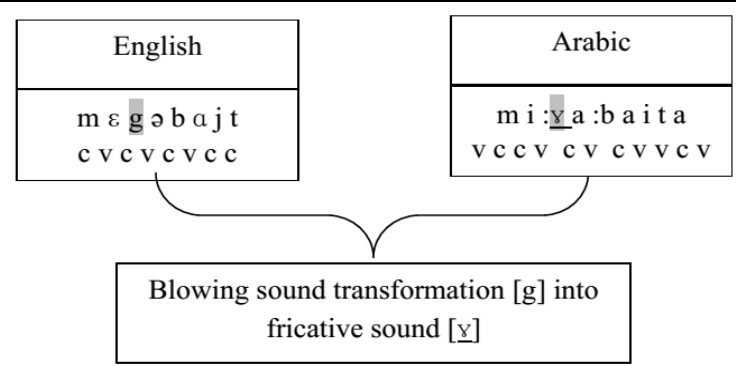

Image1. The process of intervocalic weakening from English into Arabic

In the above image, it is clear that the consonant sound transformation $[\mathrm{g}]$ that belongs to blowing consonant sound in English becomes consonant sound [ $\mathrm{\gamma}]$ which is fricative. The samples of this type can be seen in the following words.

Table10. Intervocalic Weakening in loanwords

\begin{tabular}{|c|c|c|c|c|c|}
\hline No & English & $\begin{array}{l}\text { Phonemic } \\
\text { transcription }\end{array}$ & Arabic & Orto graphic words & Phonemic transcription \\
\hline 1 & megabyte & [megəbajt] & ميغابَيَتْة & mīgābaitah & [mi:ya:baita] \\
\hline 2 & oceanographer & $\begin{array}{c}\text { [ofənagrəfər } \\
\text { om mitər] }\end{array}$ & أوقيانو غر افيّ & uqiyānugrāfiy & [Puqija:nuyra:fiy] \\
\hline 3 & gallon & [gælən] & غالون & gālūn & [ชว:lu:n] \\
\hline 4 & gas oline & [gæs olin] & غازولين & gāzūlīn & [y:ozu:li:n] \\
\hline
\end{tabular}

\subsection{Apocope}

Apocope is chunking one or more sounds from the end of words (Kridalaksana, 2008: 15). Such transformation is due to the shed of post sound words and it commonly occurs in any languages. The chunking of English loanwords normally apply to the last alphabet of verbal and nominal in reading or speaking. In the case of loanwords of English into Arabic, there is a sound chunking [k] in the words of iodic [ajədık] which is borrowed into يودي"[judi:]. It can be described in the following image:

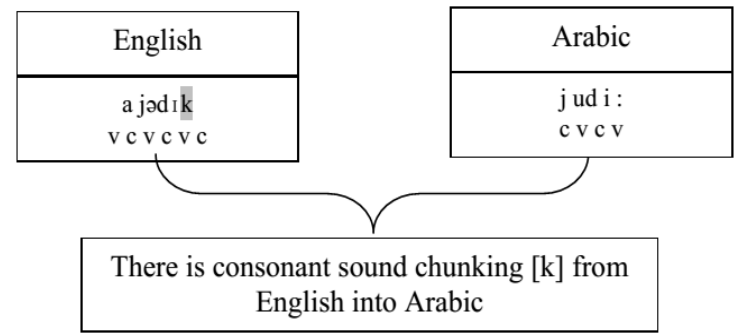

Image2. The process of Apocope from English into Arabic

Based on the above image, it shows that the chunking of consonant sound $[\mathrm{k}]$ at the post of English words into Arabic ones. The samples of sound transformation of the Apocope type from English words into Arabic are in the following table:

Table11. Apocope in loanwords

\begin{tabular}{|c|c|c|c|c|c|}
\hline No & English & $\begin{array}{l}\text { Phonemic } \\
\text { transcription }\end{array}$ & Arabic & $\begin{array}{l}\text { Orto graphic } \\
\text { transcription }\end{array}$ & $\begin{array}{l}\text { Phonemic } \\
\text { transcription }\end{array}$ \\
\hline 1 & ceramics & [səræmıks] & سير اميك & sīrāmīk & [si:ra:mi:k] \\
\hline 2 & iodic & [ajədık] & يوديي & judiyy & [judI:] \\
\hline 3 & ionic & [ajanık] & أيونيّ & ayūniyy & [ayu:nI] \\
\hline 4 & ozoniferous & [ozoniferus] & أوزونيّ & ūzūniy & [auzu:nI] \\
\hline
\end{tabular}

\subsection{Syncope}

Syncope is the missing sound in the middle of words (Kridalaksana, 2008: 154). In the case of loanwords from English into Arabic, there is a missing sound [ $\mathrm{r}$ ] in motorbus [motər bəs] that is borrowed into مطوبس [muț u:bis], as described in the image below. 


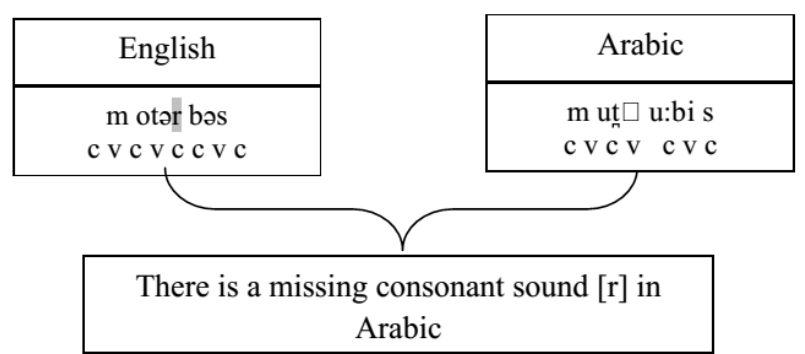

Image3. Syncope process from English into Arabic

Based on the above image, there is a missing consonant sound [r] in the middle of English words [motərbəs] that does not exist in Arabic. Based on the data, there are missing sounds of vocal and consonant. The samples of sound transformation of syncope type are presented in the table below:

Table12. Syncope in loanwords

\begin{tabular}{|c|c|c|c|c|c|}
\hline No & English & $\begin{array}{l}\text { Phonemic } \\
\text { transcription }\end{array}$ & Arabic & $\begin{array}{l}\text { Orto graphic } \\
\text { transcription }\end{array}$ & Phonemic transcription \\
\hline 1 & motorbus & [motər bəs] & مطوبس & [mutūbis] & [mutrit u:bis] \\
\hline & motorcycle & [motərsajkəl] & موتوسيكلا & [mutūsiklā] & [mutrifu:sikla:] \\
\hline 2 & meter & [mitər] & المنز & mitr & [mitru] \\
\hline
\end{tabular}

\subsection{Prosthesis}

Prosthesis is the addition of vokal or consonant in the beginning of word to ease articulation (Kridalaksana, 2008:203). In the case of loanwords from English into Arabic, there is an addition of consonant and vocal [?i] in the pre of words stereoscopic [stəro: skovpik] that is borrowed into إسْنَرْيو سْكوبيَ [?istarjusku:bij]. The sound addition is to help articulation if there is a consonant particle $[\mathrm{s}]$ and $[\mathrm{t}]$ in the word of stereoscopic. The process of prosthesis from English into Arabic is described in the following image:

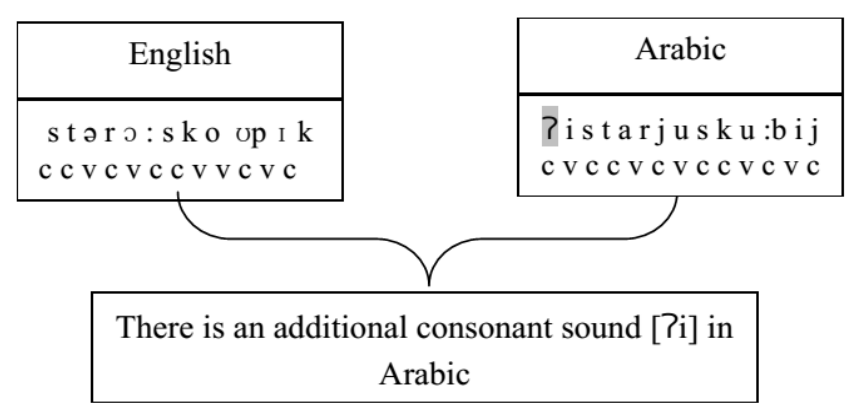

Image4. Prosthesis process from English into Arabic

Based on the image above, there is an addition of vocal and consonant [?i] in the beginning of Arabic words to ease articulation. The samples of sound transformation of prosthesis type from English into Arabic is described in the table below:

Table13. Prosthesis in loanwords

\begin{tabular}{|c|c|c|c|c|c|}
\hline No & English & $\begin{array}{l}\text { Phonemic } \\
\text { transcription }\end{array}$ & Arabic & $\begin{array}{l}\text { Orto graphic } \\
\text { transcription }\end{array}$ & $\begin{array}{l}\text { Phonemic } \\
\text { transcription }\end{array}$ \\
\hline 1 & stereoscopic & [stərっ:sk oupık] & إسْنَرَيْ سْكوبيّ & istaryuskūbiy & [Pistaryusku:biy] \\
\hline 2 & sponge & [spənd3] & الإِنْفَنْ & [isfanju] & [isfand3] \\
\hline
\end{tabular}

\subsection{Epenthesis}

Epenthesis is inserting sounds or characters into words, especially into loanwords in order to adjust with the pattern of phonologic of target language (Kridalaksana, 2008: 41). The indication of Epenthesis can be an additional vocal in the middle of words to separate two consonants. In the case of loanwords from English into Arabic, there is a sound insertion [a] in the middle of words granite [grænət] that is borrowed into الغرانيت [al-yaro:ni:t].This kind sound additional also ease the articulation if there is a consonant particle $[\mathrm{g}]$ and $[\mathrm{r}]$ in the words granite, as what described in the following image: 


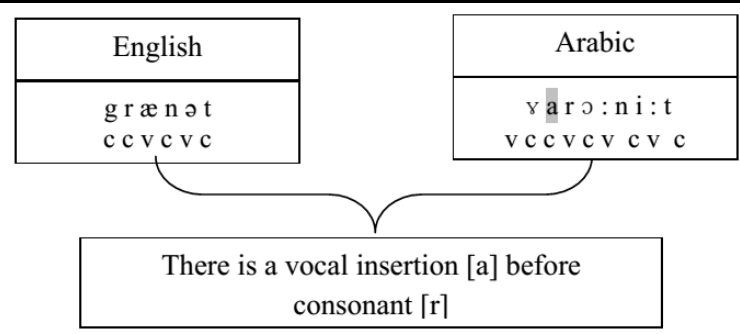

Image5. Epenthesis process from English into Arabic

Based on the above image, there is a vocal sound insertion [a] into Arabic. The samples of sound transformation of Epenthesis type in the case of loanwords are enlisted in the following table:

Table14. Epenthesis in loanwords

\begin{tabular}{|c|c|c|c|c|c|}
\hline No & English & $\begin{array}{l}\text { Phonemic } \\
\text { transcription }\end{array}$ & Arabic & $\begin{array}{l}\text { Orto graphic } \\
\text { transcription }\end{array}$ & Phonemic trancription \\
\hline 1. & automation & 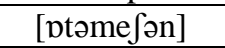 & أوتوماتيكية & [ūtūmātīkiyyah] & [?u:tu:ma:tikiyyah] \\
\hline 2. & cholesterol & [kəlestərol] & كلولسترول & [kalūlistirūl & [kalu:listiru:1] \\
\hline 3. & cyanic & [seijanik] & سِيانو جينيّ & [sijānūjīniy] & [sija:nuji:nI] \\
\hline 4. & hydraulics & [hajdroliks] & هيدروليات & [hīdrūliyyāt] & [hidro:lijjat] \\
\hline 5. & picrotoxin & [pikrotəksən] & بِكروتوكسين & [bikrūtūksīn] & [bikro:tuksi:n] \\
\hline 6. & planetarium & [plænətcriəm] & بلانيتاريوم & [balānītrāniyūm] & [bala:ni:ta:riju:m] \\
\hline 7. & proton & [protan] & برتون & [burtūn] & [baro:tu:n] \\
\hline 8. & scooter & [skutər] & سَّكُتَورة & [saktūrah] & [saktu:roh] \\
\hline 9. & nitrocellulose & [najtroscljəlos] & نَتُروستلولوز & [nitrūsalūlūz] & [nitru:salu:lu:z] \\
\hline 10. & toulidine & [tulidi'n] & تُّوليودين & [tūliyūdīn] & [tu:liju:di:n] \\
\hline
\end{tabular}

\subsection{Metathesis}

Metathesis is a position exchange of characters, sounds, or syllables in words (Kridalaksana, 2008: 106). In the case of loanwords from English into Arabic, there is a position exchange of characters or sounds [r] in the words as-tro-labe [æztro-leb] that is borrowed into الأسنطُرْلاب [allust بrla:b], as described in the following image:

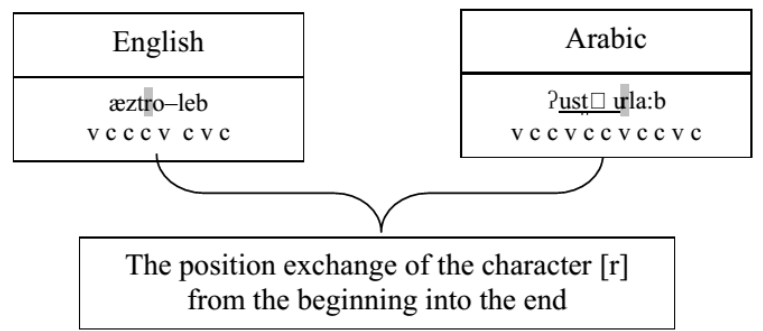

Image6. Metathesis process from English into Arabic

Based on the above image, there is a position exchange [r] at the beginning of English words into the end of Arabic one. The following table are the samples of the sound transformation of metathesis type in loanword:

Table15. Metathesis in loanwords

\begin{tabular}{|c|c|c|c|c|c|}
\hline No & English & $\begin{array}{l}\text { Phonemic } \\
\text { transcription }\end{array}$ & Arabic & $\begin{array}{l}\text { Orto graphic } \\
\text { transcription }\end{array}$ & $\begin{array}{l}\text { Phonemic } \\
\text { transcription }\end{array}$ \\
\hline 1 & cotton & [katən] & القطن & [qut $\left.{ }^{\uparrow} n\right]$ & {$\left[q_{n} t_{n}^{f} n\right]$} \\
\hline 2 & kilometer & [kəlamətər] & كيلومثر & [ki:lu:mitr] & [ki:lu:mitr] \\
\hline 3 & liter & [litər] & لتر ات & [litra:t] & [litra:t] \\
\hline 4 & meter & [mitər] & المتر & [mitru] & [mitr] \\
\hline 5 & as-tro-labe & [æztro-leb] & الأسنطرْْ لاب & [ust. urlāb] & [?ust urla:b] \\
\hline 6 & ozonometer & [ozonometer] & الأوزونومتر & [ūzūnūmitr] & [auzu:nu:mitr] \\
\hline
\end{tabular}

\subsection{Aphaeresis}

Aphaeresis is dispatching sounds or syllables in the beginning of words (Kridalaksana, 2008:3). In the case of loanwords from English into Arabic, there is dispatching sound [a] at the beginning of word iodic [ajadık] that is borrowed into يوديّ [ju:di:], as shown in the following table: 
The Transformation of Consonant Sound of English Loanwords into Arabic

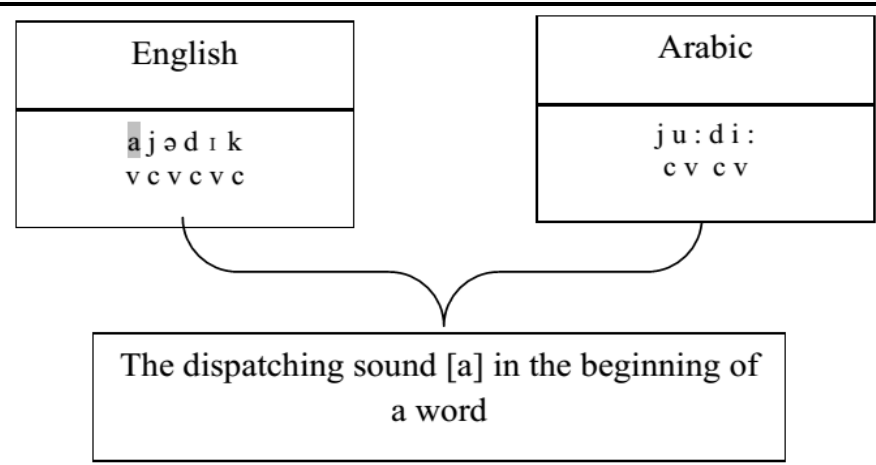

Image7. Aphaeresis process from English into Arabic

Based on the image above, there is a vocal sound dispatching [a] in English words into the missing [a] Arabic ones. The samples of the sound transformation of aphaeresis types in the loanwords are enlisted in the following table:

Table16. Aphaeresis in loanwords

\begin{tabular}{|c|c|c|c|c|c|}
\hline No & English & $\begin{array}{l}\text { Phonemic } \\
\text { transcription }\end{array}$ & Arabic & $\begin{array}{l}\text { Orto graphic } \\
\text { transcription }\end{array}$ & Phonemic transcription \\
\hline 1 & iodic & [ajədık] & يوديّ & [judiyy] & [ju:dI:] \\
\hline 2 & iodide & [ajədajd] & يُوديد & [yudīid] & [judi:d] \\
\hline 3 & iodate & [ajədat] & يودات & [yūdāt] & [ju:da:t] \\
\hline 4 & iodine & [ajədajn] & يود & [yūd] & [ju:d] \\
\hline 5 & iodoform & [ajədoform] & يودوفورم & [yūdūfūrm] & [ju:du:fu:rm] \\
\hline
\end{tabular}

\subsection{Compressing}

Compressing is a merging proses of one or more syllables at the end or mid of words. In the case of loanwords from English into Arabic, there is merging a syllable [id] in the words of hydroid [hajdroid] that is borrowed into الهُِْريّ [alhidri], as described in the following image:

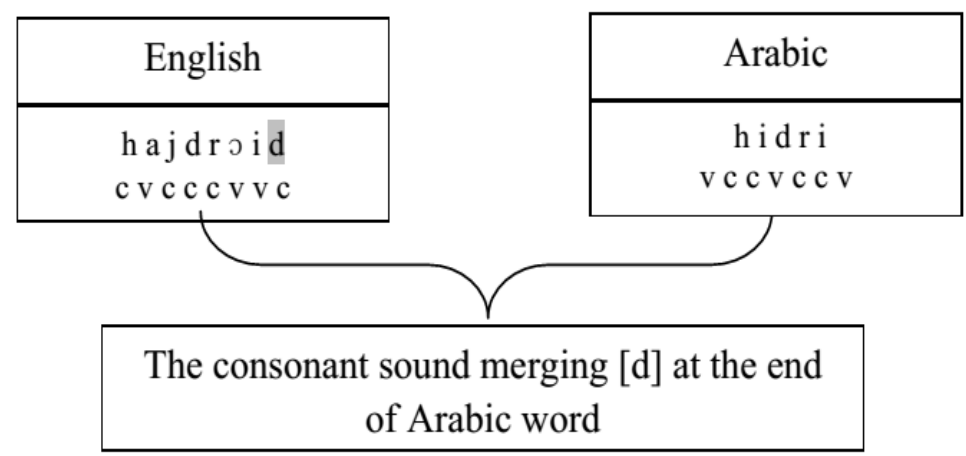

Image8. Compressing process from English into Arabic

Based on the above image, there is a merging process of a consonant [d] at the end of English words into the missing [d] of Arabic one. The samples of sound transformation of compressing type in loanwords is described in the following table:

Table17. Compressing in loanwords

\begin{tabular}{|c|c|c|c|c|c|}
\hline No & English & $\begin{array}{c}\text { Phonemic } \\
\text { transcription }\end{array}$ & Arabic & $\begin{array}{c}\text { Orto graphic } \\
\text { transcription }\end{array}$ & Phonemic transcription \\
\hline 1 & hydroid & [hajdroid] & [hīdriy] & [alhidrI] \\
\hline 2 & zincoid & [zijkoid] & [zinkī] & [zinkI] \\
\hline
\end{tabular}

\subsection{Paragogue}

Paragogue is a sound addition at the end of words to improve the tune or ease articulation (Kridalaksana, 2008: 120). The sound addition is normally suffixes in Arabic such as: ya'u'nisbah (باءالنسبة), ta' ta'nis (ت) dan ta' marbutah ('). In the case of loanwords from English into Arabic, there is a sound addition [mijjah] at the end of words azote [æzot] that is borrowed into الآوتيمية [al?azu:ti:mijjah], as described in the following table: 


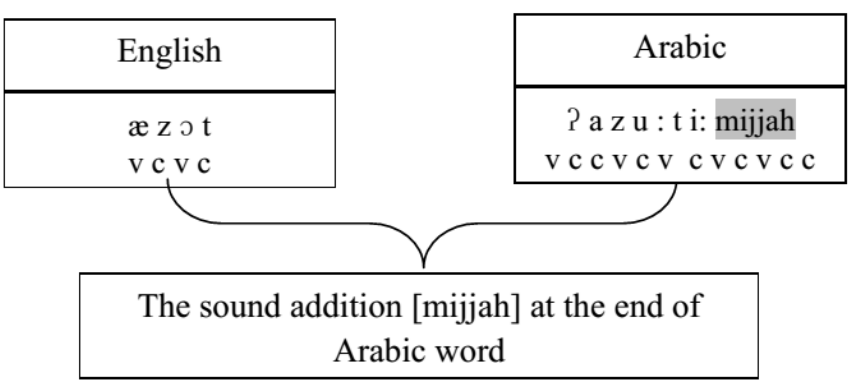

Image9. Paragogue process from English into Arabic

From the above image, there are sound additions of vocal and consonant [mijjah] in Arabic but the sounds themselves do not exist in English. The following table shows the samples of sound transformation of Paragogue type:

Table18. Paragogue in loanwords

\begin{tabular}{|c|c|c|c|c|c|}
\hline No & English & $\begin{array}{l}\text { Phonemic } \\
\text { transcription }\end{array}$ & Arabic & $\begin{array}{l}\text { Orto graphic } \\
\text { transcription }\end{array}$ & Phonemic transcription \\
\hline 1 & azote & [æzot $]$ & آزوتيمية & [āzūtīmiyyah] & [?azu:ti:mijjah] \\
\hline 2 & uranography & [jərauranography] & أور انو غر افيا & [ūrānugrāfiy ā] & [u:ro:nugh:ro:fijja:] \\
\hline 3 & cable & {$[\mathrm{kebəl}]$} & الكَبْل & [kablu] & [kablu $]$ \\
\hline 4 & chemurgy & [kemurjI $]$ & الكيميارجيا & [kī miyārujiyā] & [ki:mija:rojija:] \\
\hline 5 & seismometry & [sajzmamətrI] & السيّيزمومتريّة & [sizmūmitriyyah] & [sizmu:mətrijjah] \\
\hline
\end{tabular}

\subsection{Sound Empowerment}

In the type of sound empowerment, the voice sound is presumably stronger than the type of voiceless one. The discontinue sound is more powerful than the continue one. The consonant sound is higher that the semi-vocal one; the oral sound is more robust than glottal one; and pre and post vocals are more resilient that the middle ones (Crowley, 1992: 39). In the case of loanwords from English into Arabic, there is sound empowerment such the sound transformation of $p \rightarrow b$ in the word pantology

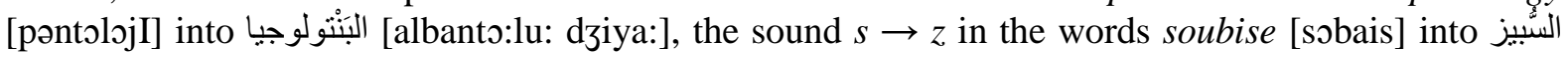
[assubi:z].

Table19. Sound empowerment in loanwords

\begin{tabular}{|c|c|c|c|c|c|c|}
\hline No. & English & $\begin{array}{l}\text { Phonemic } \\
\text { transcription }\end{array}$ & Arabic & $\begin{array}{l}\text { Orto graphic } \\
\text { transcription }\end{array}$ & Phonemic transcription & $\begin{array}{c}\text { Sound } \\
\text { transformation }\end{array}$ \\
\hline 1 & panchromatic & [peykomətik] & بانكروماتيّ & [bānkurūm ātiy] & [baykro:matI] & $\mathrm{p} \rightarrow \mathrm{b}$ \\
\hline 2 & pantology & [pəntəlojI] & بَنْتُولوجيا & [bantūlūjiyā] & [banto:lu: dziya:] & $\mathrm{p} \rightarrow \mathrm{b}$ \\
\hline 3 & paraffin & $\begin{array}{l}\text { [perəfən } \\
\text { perəfə'n] }\end{array}$ & البار افين & [bārāfīn] & [ba:ra:fi:n] & $\mathrm{p} \rightarrow \mathrm{b}$ \\
\hline 4 & petrologic & [potrolojik] & بترولوجيّ & [bitrūlūjiy] & [bitro:lu: dzI] & $\mathrm{p} \rightarrow \mathrm{b}$ \\
\hline 5 & petrologist & [pətrolojis] & البترولوجيّ & [bitrūlūjiy] & [bitro:lu: dzi:] & $\mathrm{p} \rightarrow \mathrm{b}$ \\
\hline 6 & petrology & [potralədzi] & البترولوجيا & [bitrūlūjiyā] & [bitro:1: dzija:] & $\mathrm{p} \rightarrow \mathrm{b}$ \\
\hline 7 & picogram & [pikogram] & البيكو غرام & [bīkūgrām] & [bi:ku:gro:m] & $\mathrm{p} \rightarrow \mathrm{b}$ \\
\hline 8 & picrotoxin & [pikrotoksən] & البِكروتوكسين & [bikrūtūksīn] & [bikro:tuksi:n] & $\mathrm{p} \rightarrow \mathrm{b}$ \\
\hline 9 & gyroscope & [dzajrəskop] & الجيروسكوب & [jīrūskūb] & [dzi:rusku:b] & $\mathrm{p} \rightarrow \mathrm{b}$ \\
\hline 10 & soubise & [sobais] & النُّبيز & [subīz] & [subi:z] & $\mathrm{s} \rightarrow \mathrm{Z}$ \\
\hline
\end{tabular}

\subsection{Sound Dilution}

In the type of sound dilution, the notion is in contrast with the explanation of sound empowerment (Crowley, 1992: 39). The voiceless sound is presumably weaker than the voice one. The continue sound is lower than the discontinue one; the semi-vocal sound is more inferior to the consonant one; the glottal sound is weaker than the oral one; and mid vocal is weaker than pre and post vocal (Crowley, 1992: 39). In the case of loanwords from English into Arabic, there is sound dilution such in the sound [v] $\rightarrow$ [f] in the words vibraphone [vaibrafon] into فيير افون [fibra:fu:n]. The sound [v] belongs to voice sound, meanwhile the sound [f] is voiceless displace one. The samples of sound dilution from the pre and post vocal to the mid one is not available in the data because Arabic has only pre and post vocal. The other samples of sound transformation in the dilution type are illustrated in the following table:

Table20. The sound dilution in loanwords 
The Transformation of Consonant Sound of English Loanwords into Arabic

\begin{tabular}{|c|c|c|c|c|c|c|c|}
\hline No & Distribution & English & $\begin{array}{c}\text { Phonemic } \\
\text { transcription }\end{array}$ & Arabic & $\begin{array}{l}\text { Orto graphic } \\
\text { transcription }\end{array}$ & $\begin{array}{c}\text { Phonemic } \\
\text { transcription }\end{array}$ & $\begin{array}{c}\text { Sound } \\
\text { transformation }\end{array}$ \\
\hline 1 & \multirow{5}{*}{ pre } & vanadic & [vənedik] & فاناديو ميّ & fānādiyūmī̄̄ & [fa:na:dijumI] & $\mathrm{v} \rightarrow \mathrm{f}$ \\
\hline 2 & & vanadinite & [vənedinait] & فانادِينيت & fānādīnīt & [fa:na:di:ni:t] & $v \rightarrow f$ \\
\hline 3 & & vanadium & [vənediəm] & فاناديوم & fānādiyūm & [fa:na:diju:m] & $\mathrm{v} \rightarrow \mathrm{f}$ \\
\hline 4 & & vibraphone & [vaibrafon] & فيبر افون & fibrāfūn & [fibra:fu:n] & $\mathrm{v} \rightarrow \mathrm{f}$ \\
\hline 5 & & video genic & [vidio dzənik] & فيديوي" & fīdīyūwiyy & [fi:di:jo:wi] & $\mathrm{v} \rightarrow \mathrm{f}$ \\
\hline
\end{tabular}

\subsection{Assimilation}

Asimilation is the process of sound transformation that results the sound imitation with the nearby sound (Kridalaksana, 2008: 15). Such sound transformation is commonly influenced by other sound. If a sound trasnfroms other sound, they will sound similar or typically similar. The samples of

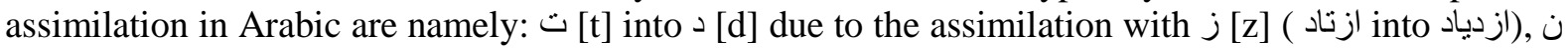

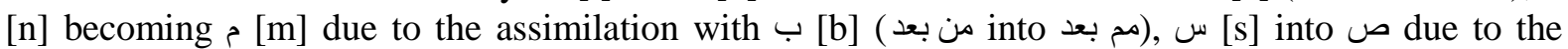

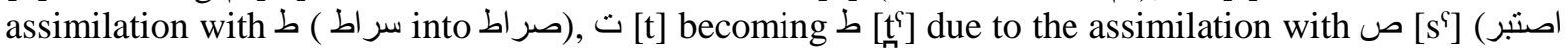
into اصطبر) (Jauhar, 2014: 170).

Based on the research on assimilation in Al-Qur'an, Kholisin (2005: 197) concludes that in terms of phonemic, assimilation in Arabic possibly occurs based on the articulation technique, sounding characters, and emphatic characters. Based on the articulation technique, a strong sound may not more superior than a weaker one, but it depends on the consonant position in words or articulation track. The samples of loanwords from English into Arabic is the sound [a] articulated into [u] in the words octane [akten] into أكتَّن [uktain]. It happens because the sound [u] belongs to post vocal. Simultaneously, the sound coming after is the sound $[\mathrm{k}]$ that is velar-plosive consonant or post consonant. Thus, the sound [a] in the words octane [akten] follows the next character articulation or assimilated into $[\mathrm{u}]$ in order to follow the post consonant sound $[\mathrm{k}]$.

\subsection{Dissimilation}

Disimilasi is a transformation of similar sound into different one (Kridalaksana, 2008: 51). The samples of dissimilation in Arabic is explained in the following case. If there are three $\sin$, the third

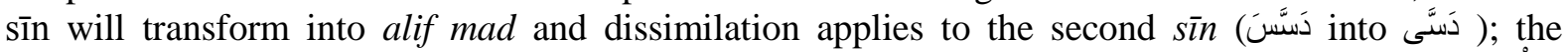
transformation of the first mim into lâm, dissimilation applies to the second mim ( جَمَلْدَ) (Jauhar, 2014: 176). The samples of dissimilation in the loanwords from English into Arabic include the sound [æ] at the beginning of words avidin [ævidən] articulated with [a] in أقيدين [aqi:di:n]. The sound [æ] is pre vocal that meets pre consonant of labio-dental [v]. Having borrowed, there is pre vocal transformation [a] that meets post consonant of uvular [q]. Therefore, it is articulated into أقيدين [aqi:di:n]. The dissimilation happens in this word in which initially the pre vocal [æ] after the pre consonant [v], transforms into pre vocal [a] meeting the post consonant [q]. The samples of sound transformation of dissimilation type in loanwords from English into Arabic can be seen in the following table:

\section{Conclusion}

Sound transformation of English loanword into Arabic occurs by adjusting the phono tactic of Arabic. The transformation is relatively close to the process of sound articulation. In this case, there are 4 sound transformations derived from the similar articulation process. The trasnformation includes sound $[\mathrm{g}]$ into $[\mathrm{k}]$ (all of them is velar plosive), $[\mathrm{p}]$ into [b] (they belong to bilabial-plosive, [s] into [z] (they are alveolar-fricative), [v] into [f] (both are labia dental-fricative). In addition, there are consonant sound transformations which their articulation process is divergent in order to differentiate from the current meaning that has existed such the sound [v] into [q] in the word avidin [ævidən] آقيدين آقيدين [a:qi:di:n]. If the sound [v] is articulated with [f], the word will transform into [a:fi:di:n]. Therefore, such words will be similar with certain vocabulary in Arabic. In the case of the sound transformation [S] into [[k], in the word galvanism [galvanisəm] becoming [َْفانية [kalfa:nijjah], the sound [g] is articulated with [k]. If it is articulated with [y], it will be غُفْانية [yalfa:nijjah]. Thus, such words will be similar to the word الغلفة meaning 'kulup' in Arabic. Meanwhile, from the perspective of sound transformation type, Epenthesis sound transformation is the commonly occurred because it follows Arabic syllable patterns and Arabic sound ones.

\section{REFERENCES}


Abbound, Peter.F, 1996, Elementary Modern Standard Arabic 2, USA: The United States of America Press

Al-Khatib, Ahmed Sh, 1980, A New Dictionary of Scientific and Technical Terms, Libanon: Maktabah Lubnan.

Amīn, Muhammad Syauqi, dkk, 1984, Majmū'atul Qarārāt al- 'Ilmiyyah, Cairo: al-Hai'ah al- 'Āmmah lisyūni al-Mațāb'i al-Amīriyyah

At-Tunjiy, Muhammad, 2005, Al-Mu'arrab wad-Dakhīl fil-Lughah al- 'Arabiyah wa Ādäbiha, Beirut: Darul Ma rifah.

Ba'albaky, Munir, 2009, Al-Mawrid: A Modern English Arabic Dictionary, Beirut: Dārul-'IlmililMalayin.

Ba'albaky, Rohi, 1993, A Modern Arabic-English Dictionary, Beirut: Dar El-Ilm lil Malayin.

Chejne, Anwar G.t.t., Bahasa Arab dan Peranannya dalam Sejarah (The Arabic Language: its Role in History), alih bahasa Aliudin Mahjudin, Jakarta: Pusat Pembinaan dan Pengembangan Bahasa.

Crowley, Terry, 1987, An Introduction to Historical Linguistic, University of Papua New Guinea Press, University of the South Pacific, Papua New Guinea 1992, An Introduction to Historical Linguistic, New York: Oxford University Press.

Haugen, Einar, 1950, “The Analysis of Linguistic Borrowing”, Linguistic vol. 26 no. 2,

Hadi, Syamsul, 2005, Glosarium Kata dan Istilah Asing dalam Bahasa Arab, Yogyakarta: Penerbitan Sastra Asia Barat FIB UGM.

Hockett, Charles F. 1958. A Course in Modern Linguistics. Second Edition. New York: The Macmillan Company.

Jauhar, Nasruddin Idris, 2014, Fonologi Bahasa Arab untuk Penutur Indonesia, Sidoarjo: Lisan Arabi

Khasārah, Mamduh Muhammad, 2008, 'Ilmu al-Musthalah wa Thara'iq Wad'i al-Musthalahāt fi al'Arabiyah, Darul Fikr, Damaskus.

Kholisin, 2015, “Pola Asimilasi dalam Bahasa Arab: Kajian Morfofonemis Asimilasi dalam Al-Qur'an”, Jurnal Bahasa dan Seni, Tahun 33,Vol.2, hal.9-23

Kridalaksana, Harimurti,2008, Kamus Lingustik, Jakarta: Gramedia.

Mish, 1993, Merriam Webster's Collegiate Dictionary, U.S.A: Merriam Webster Incorporated.

Munawir, Ahmad Warson, 1984, Kamus Al-Munawwir, PP Al-Munawwir, Yogyakarta.

Sloat, Clarence, 1978, Introduction to Phonology, Prentice Hall: Englewood Clif fs, N.J.

Sudaryanto. 1986. Metode Linguistik: Ke Arah Memahami Metode Linguistik. Yogyakarta: GMU Press

Tim Penyusun Kamus Atlas, 2005, Atlas Encyclopedic Dictionary English-Arabic, Madinah: AsSyirkah ad-Dauliyyah Littibā'ah.

Weinreich, Uriel, 1953, Languages in Contact: Finding and Problems, Mounton:the Haque.

www. Ahram.org.eg, accessed

www. Al-Jazeera.com, accessed

\section{AUTHOR's BIOGRAPHY}

Dr. Rika Astari, S.S. M.A, was born in Palembang, 6 Januari 1980. She teaches introduction to Arabic Linguistic, phonology, Semantic and Arabic Lexicology. Her Educational Background, She completed Bachelor Degree in Arabic literature from Ahmad Dahlan University Yogyakarta in 2005, Master degree in Middle East Studies of Gadjah Mada University in 2008, Doctorate in Middle East Studies Gadjah Mada University in 2015. astari.rika@yahoo.co.id 